\section{Anaesthesia for the patient with neonatal adrenoleukodystrophy}

Roy E. Schwartz MD, Stephen A. Stayer MD, Carol A. Pasquariello MD, David A. Lowe MD, Carl J. Foster MD*
The authors present and discuss the care of a nine-monthold with neonatal adrenoleukodystrophy who required general anaesthesia for gastrointestinal endoscopy. Neonatal adrenoleukodystrophy is an inherited disorder of peroxisomal enzymes. Anaesthetic care may be affected by the presence of hypotonia, liver function abnormalities, gastroesophageal reflux, and impaired adrenocortical function. Preoperative sedation is contraindicated because of the risk of precipitating airway obstruction due to pre-existing hypotonia. Anaesthetic induction and tracheal intubation should be performed to minimize the risk for aspiration of gastric contents. The choice of muscle relaxant should take into account the pre-existing hypotonia as well as the possibility of hyperkalaemia in response to succinylcholine. Anaesthetic agents known to decrease the seizure threshold should be avoided in patients with a seizure disorder. In addition, anaesthetic agents that rely on the liver for metabolism should be used with caution in patients with cirrhosis. When time permits, these patients should be screened for adrenocortical insufficiency before surgery, and perioperative steroid coverage is advisable when preoperative testing of adrenocortical function is not feasible. While these patients eventually die after progressive deterioration, full recovery from the effects of anaesthesia and surgery can be achieved with attention to neurological, metabolic, and physical problems.

Les auteurs présentent et commentent la conduite anesthésique d'un enfant de neuf mois porteur d'adrénoleucodystrophie qui doit subir une endoscopie sous anesthésie générale. L'adrénoleucodystrophie néonatale est un désordre congénital affectant

\section{Key words}

ANAESTHESIA: paediatric;

ENZYMES: peroxisomes;

SYNDROMES: adrenoleukodystrophy.

From the Department of Anesthesia and Critical Care, St. Christopher's Hospital for Children, Philadelphia, PA, and Albert Einstein Medical Center*, Department of Anesthesia, Philadelphia, PA.

Address correspondence to: Dr. Roy E. Schwartz, Department of Anesthesia and Critical Care, St. Christopher's Hospital for Children, Erie Avenue at Front Street, Philadelphia, PA 19134 (215) 427-5220.

Accepted for publication lst October, 1993. les enzymes péroxysomatiques. La conduite anesthésique peut être affectée par l'hypotonie, des anomalies de la fonction hépatique, un reflux gastro-oesophagien et une altération de la fonction adrénocorticale. La prémédication est contre-indiquée par le risque de provoquer une obstruction des voies respiratoires supérieures par hypotonie. Il faut minimiser le risque d'aspiration du contenu gastrique. Le choix du myorésolutif doit être guidé par la présence d'hypotonie aussi bien que par la possibilité d'hypekaliémie en réponse à la succinylcholine. Les anesthésiques susceptibles d'abaisser le seuil convulsif doivent être évités. Les agents anesthésiques métabolisés par le foie doivent être utilisés avec prudence chez l'enfant cirrhotique. Si le temps le permet, il faut évaluer la fonction adrénocorticale avant la chirurgie; autrement il est conseillé de préparer le malade avec des stéroïdes. Alors que ces malades meurent éventuellement par détérioration progressive, la récupération postanesthésique et postopératoire complètes peuvent être réalisées en portant attention aux problèmes neurologiques, métaboliques et physiques.

Neonatal adrenoleukodystrophy (NALD) is an inherited disorder of peroxisomal enzymes. The clinical manifestations of this syndrome are severe weakness, hypotonia, seizures, and anatomical abnormalities of the eyes, liver, kidneys, and bones. ${ }^{1}$ The anaesthetic considerations for a similar disease, Pelizaeus-Merzbacher disease, have recently been described. ${ }^{2}$ We report a typical case of NALD and discuss the neurological, metabolic and physical problems associated with this disease and the implications for the anaesthetist.

\section{Case report}

A nine-month-old, $5 \mathrm{~kg}$ boy with NALD presented to the emergency department with a three-day history of black stools and bleeding from his gastrostomy site. He had a history of severe hypotonia, seizures since the age of two weeks treated with phenobarbitone, and gastroesophageal reflux since the age of one week treated surgically with a Nissen fundoplication at the age of one month.

Hypovolaemia was treated with $10 \mathrm{ml} \cdot \mathrm{kg}^{-1}$ of packed red blood cells in the emergency room. His initial laboratory studies revealed a haemoglobin concentration of 
$7.0 \mathrm{~g} \cdot \mathrm{dl}^{-1}$, platelet count 312,000 , AST $390 \mathrm{IU} \cdot \mathrm{L}^{-1}$ (normal $<67 \mathrm{IU} \cdot \mathrm{L}^{-1}$ ), ALT $183 \mathrm{IU} \cdot \mathrm{L}^{-1}$ (normal $<$ $54 \mathrm{IU} \cdot \mathrm{L}^{-1}$ ) and $\gamma \mathrm{GTP} 114 \mathrm{IU} \cdot \mathrm{L}^{-1}$ (normal 5-35 $\mathrm{IU} \cdot \mathrm{L}^{-1}$ ), PT 13.4 seconds (normal $11.3 \mathrm{sec}$ ), PTT 33 sec (normal 28.2 seconds).

The following day the patient was brought to the operating room for endoscopy and sclerotherapy. No premedication was given and the patient arrived in the operating room with a 22-gauge $i v$ cannula in place. Noninvasive monitors (ECG, Doppler blood pressure, axillary temperature, precordial stethoscope, and pulse oximetry) were applied. After atropine $0.02 \mathrm{mg} \cdot \mathrm{kg}^{-1} i v$, a modified rapid-sequence induction was performed with thiopentone $5 \mathrm{mg} \cdot \mathrm{kg}^{-1}$, pancuronium $0.1 \mathrm{mg} \cdot \mathrm{kg}^{-1}$ and mask ventilation with cricoid pressure until the trachea was intubated. Anaesthesia was maintained with isoflurane $1 \%$ in 50/50 oxygen and air. Upper endoscopy revealed gastritis as the source of bleeding. Residual neuromuscular blockade was antagonized with neostigmine 0.07 $\mathrm{mg} \cdot \mathrm{kg}^{-1}$ and atropine $0.02 \mathrm{mg} \cdot \mathrm{kg}^{-1}$. The trachea was extubated when the patient demonstrated sustained extremity movement against gravity, protective airway reflexes, spontaneous eye opening, and a regular respiratory pattern. The remainder of the patient's recovery was uneventful.

\section{Discussion}

Neonatal adrenoleukodystrophy is one of a group of genetically determined disorders of peroxisomal function. The mode of inheritance is typically autosomal recessive. This group of disorders also includes X-linked adrenoleukodystrophy, Zellweger's syndrome, Refsum's disease, among others. ${ }^{1}$ The incidence of X-linked adrenoleukodystrophy is 1 in 100,000 and the combined incidence of all other peroxisomal disorders is 1 in 25,000 to 50,000 .

Peroxisomes are enzyme-producing organelles which are present in all cells except mature erythrocytes. There are over $\mathbf{4 0}$ peroxisomal enzymes identified that perform many functions including: (1) biosynthesis of plasmalogens (constituents of all membranes that are particularly abundant in myelin); (2) bile acid synthesis (accounting for the abnormally high levels of bile acid intermediates observed in some of the peroxisomal disorders); and (3) fatty acid metabolism. ${ }^{3}$ Peroxisomal disorders are classified into two major groups. Group I consists of disorders of peroxisomal biogenesis where the organelle fails to form or to be maintained, resulting in multiple enzyme deficiencies. Group II comprises disorders in which a single genetically determined peroxisomal deficiency is detected. NALD is part of Group I peroxisomal disorders as is Zellweger's syndrome, infantile Refsum's disease, and hyperpipecolic acidemia. ${ }^{3}$ Patients with Zellweger's syndrome have the most recognizable and severe form of the peroxisomal disorders, rarely living for more than a few months after birth. They have a typical facial appearance with a high forehead, upslanting palpebral fissures, hypoplastic supraorbital ridges, and epicanthal folds. They suffer from severe weakness, hypotonia, seizures and eye abnormalities such as cataracts, glaucoma, and pigmentary retinopathy. Demonstrable peroxisomes are absent in the kidney and liver. The liver is frequently enlarged, fibrotic, and often cirrhotic; and renal cysts may be present. There is a characteristic disorder of neuronal migration in the brain which contributes to seizures, hypotonia and delayed psychomotor development. Cardiac abnormalities have been described, most often ventricular septal defects (32\%) and aortic abnormalities (22\%). ${ }^{3}$

The pathologic features of NALD are similar to Zellweger's syndrome but less severe. The peroxisomal deficiency in the liver is less pronounced; however, liver function abnormalities are common. While the neuronal migrational defects are less severe, there is greater involvement of white matter than in Zellweger's syndrome accounting for hypotonia. The clinical course is variable with severely affected infants dying within six months of life without any psychomotor development. Others are severely retarded and moderately dysmorphic and may survive into the mid-teens. Most patients with NALD have a diminished adrenocortical response to ACTH stimulation, but clinical adrenal insufficiency is rarely observed. Mental age rarely advances beyond one year of development, and the loss of developmental milestones may occur between three and five years of age due to the progression of the leukodystrophy. ${ }^{3}$

Disorders of peroxisomal biogenesis should be suspected in infants or children who are dysmorphic, hypotonic, and present with seizures in the neonatal period. Psychomotor retardation has been noted in all patients with the diagnoses. Neonatal adrenoleukodystrophy can be diagnosed by biochemical abnormalities such as elevated plasma levels of long chain fatty acids, pipecholeic acid, phytanic acid, and bile acid intermediates. Diminished levels of plasmalogen in red cells is often found. ${ }^{3}$

The issues to be considered when developing an anaesthetic plan include: profound mental retardation, seizure disorder, hypotonia, liver function abnormalities, gastroesophageal reflux, and possibly impaired adrenocortical function.

In addition to generalized hypotonia, hypotonia of the pharyngeal muscles responsible for soft tissue airway obstruction is likely. Preoperative sedation is contraindicated because of the risk of worsening airway obstruction. Postoperatively, extended observation in the recovery room is warranted because airway obstruction may be aggravated by residual anaesthesia or traumatic oedema. These patients have no intrinsic defect of the muscle and are 
at no increased risk for the development of malignant hyperthermia. There are no reports associating this disease with malignant hyperthermia. While succinylcholine is often considered the drug of choice for rapid sequence induction because of its rapid onset and short duration of action, the risk of hyperkalaemia secondary to succinylcholine is unknown in these patients. There is one report of an exaggerated release of potassium after the administration of succinylcholine in a patient with multiple sclerosis (a disease which is associated with demyelination). ${ }^{4}$ Therefore, although the risk of succinylcholineinduced hyperkalaemia may be small, it is probably best to avoid the use of succinylcholine. Because of the preexisting hypotonia, neuromuscular blockade is best achieved with a short-acting, nondepolarizing muscle relaxant. Even though pancuronium was used successfully in this case, atracurium, vecuronium, or mivacurium would have been a better choice for muscle relaxation becuase of their shorter duration of action. Careful padding and positioning of these patients is particularly important because of the demineralization of bones and the ligamentous laxity that occurs with diffuse hypotonia and muscle wasting.

These patients have an increased incidence of gastroesophageal reflux, most likely due to altered intrinsic gastric muscle tone, ${ }^{5}$ and many eventually require fundoplication for reflux. In patients who have not undergone fundoplication, metoclopramide and $\mathrm{H}_{2}$ antagonists should be given as premedication. After intravenous induction of anaesthesia, cricoid pressure should be applied until the airway is protected by an endotracheal tube to prevent passive regurgitation of gastric contents.

Anti-convulsants should be continued throughout the perioperative period in those patients with a seizure disorder. Anaesthetic agents that are potentially epileptogenic, such as enflurane, ketamine, and etomidate, should be avoided. ${ }^{6}$ Patients with cirrhosis may have associated oesophageal varices and an abnormal duration of action of drugs that rely on the liver for excretion such as vecuronium. $^{7}$

Most patients with NALD have an impaired response of the adrenal cortex to ACTH stimulation, but clinically apparent adrenal insufficiency is infrequent. When time permits preoperatively, these patients should be screened for adrenocortical insufficiency with an ACTH stimulation test to determine the need for preoperative steroids. ${ }^{1}$ Perioperative steroid coverage is advisable if preoperative testing of adrenocortical function is not feasible.

In conclusion, NALD is a complicated, progressive, and lethal disorder involving multiple organ systems. The anaesthetic plan for each individual must be based on the specific organ systems involved. The plan should take into consideration that these patients may have seizures, hypotonia, mental retardation, gastroesophageal reflux, liver function abnormalities and impaired adrenocortical function. While these patients eventually die after progressive deterioration, a full recovery from the effects of anaesthesia and surgery can be achieved with attention to neurological, metabolic, and physical problems.

\section{References}

1 Moser HW. Peroxisomal disorders: In: Behrman RE, Kleigman RM, Nelson WE, Vaughan VC (Eds.). Nelson Textbook of Pediatrics, 14th ed. Philadelphia: WB Saunders, 1992: 338-42.

2 Tobias JD. Anaesthetic considerations for the child with leukodystrophy. Can J Anaesth 1992; 39: 394-7.

3 Moser HW. Peroxisomal diseases. In: LA Barnes (Ed.). Advances in Pediatrics, Vol. 36. Chicago: Year Book Medical Publishers, 1989, 1-38.

4 Cooperman LH. Succinylcholine-induced hyperkalemia in neuromuscular disease. JAMA 1970; 213: 1867-71.

5 Boix-Ochoa J. Gastroesophageal reflux. In: Welch KJ, Randolph JG, Ravitch MM, O'Neill JA Jr, Rowe MI (Eds.). Pediatric Surgery, 4th ed. Chicago: Year Book Medical Publishers, 1986: 712-20.

6 Drummond JC, Shapiro HM. Cerebral physiology. In: Miller RD (Ed.). Anesthesia, 3rd ed. New York: Churchill Livingstone, 1990, 621-58.

7 Maze M, Prager MC. Anesthesia and the liver. In: Miller RD (Ed.). Anesthesia, 3rd ed. New York: Churchill Livingstone, 1990, 1809-28. 